\title{
INSECTICIDAL POTENTIAL OF CITRUS AND MANGO ESSENTIAL OILS AND SELECTED CONSTITUENTS ON SILVERLEAF WHITEFLY ${ }^{1}$
}

\author{
NICOLLE DE CARVALHO RIBEIRO ${ }^{2}$, CLAUDIO AUGUSTO GOMES DA CAMARA ${ }^{3 *}$, JOÃO PAULO RAMOS DE \\ MELO $^{2}$, MARCÍLIO MARTINS DE MORAES ${ }^{3}$
}

\begin{abstract}
Bemisia tabaci is a cosmopolitan pest responsible for causing harm to crops in the agricultural hub of Petrolina in the state of Pernambuco, Brazil. We investigated the lethal and sublethal effects of vapors from essential oils obtained through hydrodistillation of the peels of four species of Citrus and the latex from Mangifera indica (var. "rosa" and "espada") on B. tabaci. The chemical analysis by Gas chromatography coupled to mass spectrometry of the oils led to the identification of 71 constituents, with limonene as the major component of the Citrus oils and terpinolene as the major component of the $M$. indica oils. B. tabaci was more susceptible to Citrus aurantiifolia $\left(\mathrm{LC}_{50}=0.70 \mu \mathrm{L} \mathrm{L}^{-1}\right.$ air) and $C$. limon $\left(\mathrm{LC}_{50}=1.77 \mu \mathrm{L} \mathrm{L}^{-1}\right.$ air) oils, which had the same level of toxicity. Citrus and $M$. indica oils also led to a reduction in the fecundity of the pest. The lethal and sublethal action of the constituents linalool, $\alpha$-terpineol, $\alpha$-pinene, $\beta$-pinene, terpinolene and limonene is also discussed. The toxicity of the oils investigated herein associated with the reduction in fecundity is a considerable advantage in the management of B. tabaci. However, for practical use of these oils as a novel insecticide to proceed, further research is required to address safety issues for human health and determine the formulation to improve the insecticidal potency, stability and cost-benefit ratio.
\end{abstract}

Keywords: Insecticidal activity. Fumigation. Fecundity. Limonene. Terpinolene.

\section{POTENCIAL INSETICIDA DOS ÓLEOS ESSENCIAIS DE CITRUS E MANGA E CONSTITUINTES SELECIONADOS SOBRE MOSCA BRANCA}

RESUMO - Bemisia tabaci é uma praga cosmopolita e responsável por causar prejuízos aos agricultores no Polo agrícola de Petrolina-PE. Os efeitos letal e subletal dos vapores dos óleos essenciais obtidos por hidrodestilação de quatro espécies de Citrus e do látex Mangifera indica var. rosa e espada, foram investigados sobre B. tabaci. Análise química por cromatografia gasosa acoplado à espectrometria de massa dos óleos permitiu a identificação de 71 constituintes, sendo limonene o principal dos óleos de Citrus e terpinolene para os de $M$. indica. A susceptibilidade de B. tabaci foi maior para os óleos de Citrus aurantiifolia $\left(\mathrm{CL}_{50}=0,70 \mu \mathrm{L}\right.$ $\mathrm{L}^{-1}$ air) e $C$. limon $\left(\mathrm{CL}_{50}=1,77 \mu \mathrm{L} \mathrm{L}^{-1}\right.$ air), que apresentaram o mesmo nível de toxicidade entre si. Além da toxicidade, os óleos de Citrus e $M$. indica também atuaram na redução da fecundidade de $B$. tabaci. A ação letal e subletal dos constituintes, Linalol, $\alpha$-terpineol, $\alpha$-pineno, $\beta$-pineno, terpinoleno e limoneno também é discutida. A toxicidade associada com a redução da fecundidade dos óleos aqui investigados é uma grande vantagem para o manejo de $B$. tabaci. No entanto, para o uso prático destes óleos como novo inseticida, mais pesquisas são necessárias sobre questões de segurança para a saúde humana e formulação para melhorar a potencialidade inseticida, estabilidade e custo benéfico.

Palavras-chave: Atividade inseticida. Fumigação. Fecundidade. Limoneno. Terpinoleno.

\footnotetext{
"Corresponding author

${ }^{1}$ Received for publication in $04 / 10 / 2019$; accepted in $12 / 10 / 2019$.

Paper extracted from the doctoral thesis of the first author.

${ }^{2}$ Department of Agronomy, Federal Rural University of Pernambuco, Recife, PE, Brazil; nicolle.cr@gmail.com - ORCID: 0000-0003-2617 -9750, joaopaulorm@hotmail.com - ORCID: 0000-0002-1301-7763.

${ }^{3}$ Department of Chemistry, Federal Rural University of Pernambuco, Recife, PE, Brazil; claudio_agc@hotmail.com - ORCID: 0000-00018508-1230, marciliomartins14@yahoo.com.br - ORCID: 0000-0002-7597-6775.
} 


\section{INTRODUCTION}

The agricultural hub in the state of Pernambuco in northeast Brazil has exhibited accelerated growth since the installation of irrigated systems in the municipality of Petrolina in the 1970s. To increase the production of vegetable crops for the supply of large cities, protected farming technology, such as non-climatized greenhouses, was introduced in the 1990s (REIS, 2005). Nonetheless, crop losses continue to be frequent in protected crops and, depending on the time of the year, are quite high due to the attacks of pests, such as the silverleaf whitefly, Bemisia tabaci biotype B (Genn.) (Homoptera: Aleyrodidae). This occurs because $B$. tabaci has high reproductive potential as well as rapid adaptability to new hosts and environments due to its considerable genotypic plasticity (MALUMPHY, 2004). The main form of controlling this pest is through the use of conventional insecticides. However, the continuous use of such products has contaminated the ecosystem (DAMALAS; ELEFTHEROHORINOS, 2011) and led to populations of the pest to develop resistance to the active ingredients of conventional products, making its control increasingly more difficult (BARRO et al., 2011).

Due to the recognition of the biological properties of essential oils against several arthropods (ISMAN; GRIENEISEN, 2014), the interest in this plant derivative has increased significantly since the 1990s. However, few reports are found in the literature reporting the properties of essential oils from Citrus and Mangifera species on B. tabaci. Northeast Brazil is a producing region of tropical fruits belonging to the families Anarcadiaceae and Rutaceae, such as mango, lemon and tangerine, which are known for the production of essential oils. These fruits are consumed fresh or through industrially processed items in the form of juices, jams, sweets and ice cream, which generates an enormous volume of agroindustrial waste. Thus, a viable alternative to conventional pesticides may be found in novel molecules or efficient, environmentally safer products made from the waste of these fruits with the aim of formulating a pesticide for the control of $B$. tabaci in protected crops of Petrolina.

Our research group reported the susceptibility of Tetranychus urticae (Koch) (Acari: Tetranychidae), which is an important agricultural pest, to fumigation with the vapors of essential oils from the peels of Citrus sinensis L. Osbeck (Rutaceae) and Citrus aurantium (L.) Burm.f. (Rutaceae) (ARAÚJO JÚNIOR et al., 2010). More recently, we reported that essential oils from the peels of Citrus aurantiifolia (Christm.) Swingle (Rutaceae) and Citrus reticulata Blanco (Rutaceae) were active against Sitophilus zeamais (Motsch.) (Coleoptera: Curculionidae) through the cuticle, digestive and respiratory systems (FOUAD;
CAMARA, 2017). Here, our interest is to determine the chemical composition of four species of Citrus and two varieties of Mangifera indica L. (Anacardiaceae) grown in northeast Brazil and evaluate toxicity by fumigation and the effect on $B$. tabaci fecundity. The lethal and sublethal effects of six constituents of the oils are also discussed.

\section{MATERIAL AND METHODS}

The experiments were performed under laboratory conditions from January to December 2013.

\section{Collection of plant material}

Citrus spp. and Mangifera indica L. fruits were collected in the municipality of Santana do Mundaú, Alagoas State ( $\left.9^{\circ} 10^{\prime} 16.5^{\prime \prime S} 36^{\circ} 12^{\prime} 15.1 " \mathrm{~W}\right)$, and in a fragment of Atlantic forest of Pernambuco $\left(08^{\circ} 12^{\prime} 40.1^{\prime \prime} \mathrm{S} \mathrm{34^{ \circ }} 95^{\prime} 22.3^{\prime \prime} \mathrm{W}\right)$, respectively. The plants were identified by a botanist from the Federal Rural University of Pernambuco - UFRPE. Vouchers of both samples were mounted and deposited in the Vasconcelos Sobrinho Herbarium of UFRPE under the following numbers: $48734=$ Citrus aurantiifolia (Christm.) Swingle (Rutaceae); $48736=$ Citrus limon (L.) Burm.f. (Rutaceae); $48738=$ Citrus reticulata Blanco (Rutaceae); $48740=$ hybrid, Citrus reticulate Blanco x Citrus sinensis Osbeck (Rutaceae), $363=$ Mangifera indica var. "rosa" and $364=$ Mangifera indica var. "espada".

\section{Chemicals}

Constituents were used as standards in the identification of volatile compounds in the oils investigated and eugenol was used as the positive control. Linalool, $\alpha$-terpineol, $\alpha$-pinene, $\beta$-pinene, terpinolene and limonene were selected for the bioassays due to the fact that these compounds were identified oils, are commercially available and have biological properties that have been reported in the literature (RATHORE; NOLLET, 2017).

\section{Isolation of essential oils}

Essential oils from fresh fruit peels of $C$. aurantiifolia (100 g), C. limon (100 g), C. reticulata Blanco $(100 \mathrm{~g}), C$. reticulate Blanco x Citrus sinensis (100 g), and latex of fruits of $M$. indica var. "rosa" (100 g) and M. indica var. "espada" (100 g), were obtained by hydrodistillation using a modified Clevenger apparatus for $4 \mathrm{~h}$. The oil layers were separated and dried over anhydrous sodium sulfate, stored in hermetically sealed glass containers, and kept at a low temperature $\left(-5^{\circ} \mathrm{C}\right)$ until the repellent assays and analysis. Total oil yields were expressed as percentages $(\mathrm{g} / 100 \mathrm{~g}$ of fresh plant material). 
All experiments were carried out in triplicate.

\section{Gas chromatography-FID analysis}

Gas Chromatography (GC) identification was carried out using a Hewlett-Packard 5890 Series II GC apparatus equipped with a flame ionization detector (FID) and a non-polar DB-5 fused silica capillary column $(30 \mathrm{~m} \times 0.25 \mathrm{~mm} \times 0.25 \mu \mathrm{m}$ film thickness) ( $\mathrm{J}$ and $\mathrm{W}$ Scientific). The oven temperature was programmed from 60 to $240{ }^{\circ} \mathrm{C}$ at a rate $3{ }^{\circ} \mathrm{C} \mathrm{min}^{-1}$. Injector and detector temperatures were $260^{\circ} \mathrm{C}$. Hydrogen was used as the carrier gas at a flow rate of $1 \mathrm{~mL} \mathrm{~min}^{-1}$ in split mode (1:30). The injection volume was $0.5 \mu \mathrm{L}$ of diluted solution $(1 / 100)$ of oil in $n$-hexane. The percentage of each compound was obtained from GC-FID peak areas in the order of the DB-5 column elution and expressed as the relative percentage of the area of the chromatograms. Analysis was conducted in triplicate.

\section{Gas chromatography-mass spectrometry analysis}

The GC-MS analysis of the essential oils was carried out using a Varian 220-MS IT GC system with a mass selective detector, mass spectrometer in EI $70 \mathrm{eV}$ with a scan interval of $0.5 \mathrm{~s}$ and fragments from 40 to $550 \mathrm{Da}$. fitted with the same column and temperature program as that for the GC-FID experiments, with the following parameters: carrier gas $=$ helium; flow rate $=1 \mathrm{~mL} \mathrm{m^{-1 }}$; split mode $(1: 30)$; injected volume $=1 \mu \mathrm{L}$ of diluted solution $(1 / 100)$ of oil in $n$-hexane.

\section{Identification of components}

Identification of the components was based on GC-MS retention indices with reference to a homologous series of $\mathrm{C}_{8}-\mathrm{C}_{40}$ n-alkanes calculated using the Van den Dool and Kratz equation (DOOL; KRATZ, 1963) and by computer matching against the mass spectral library of the GC-MS data system (NIST version 14 and WILEY version 11) and coinjection with authentic standards as well as other published mass spectra (ADAMS, 2007). Area percentages were obtained from the GC-FID response without the use of an internal standard or correction factors.

\section{Acquisition and rearing of Bemisia tabaci biotype b}

Specimens of Bemisia Tabaci Biotype B were obtained from the Agronomic Institute of Campinas (IAC) in São Paulo/Brazil, and since then maintained in the Laboratory of Chemical Investigation of Natural Insecticides of the Federal Rural University of Pernambuco, Brazil. B. tabaci organisms were reared at a temperature of $25 \pm 1{ }^{\circ} \mathrm{C}$, relative humidity of $65 \pm 5 \%$ and a 12 -h photoperiod and without any exposure to insecticides. The breeding method was adapted from Ribeiro et al. (2010).

\section{Fumigant toxicity}

The fumigant method used to assess the toxicity of the essential oils (Citrus spp. and Mangifera indica) vapors against $B$. tabaci was as that employed by Ribeiro et al. (2010). Hermetically sealed glass containers with capacity of $1.0 \mathrm{~L}$ were used as test chambers. Leaflets from the common bean cultivar "Carioca", collected 25 to 40 days after the seeds had been sown, were used as supports. To keep leaflet turgor, these leaflets were placed in vials (5 cm height) with cotton plugs moistened with distilled water, then transferred to the fumigation chamber. With the aid of a vacuum adapter, about 15 pairs of whitefly were placed in each fumigation chamber. A filter paper strip $(5 \times 2 \mathrm{~cm})$ that worked by releasing the oil that was being evaluated was attached to the center of the inner side of the fumigation chamber lid. Different oil and eugenol concentrations were added with the aid of an automatic pipette. The concentrations of essential oils ranged from 1.0 to $7.0 \mu \mathrm{L} \mathrm{L}^{-1}$ air (C. reticulata), 3.0 to $9.0 \mu \mathrm{L} \mathrm{L}^{-1}$ air (C. sinensis x C. reticulata), 0.125 to $5.0 \mu \mathrm{L} \mathrm{L}^{-1}$ air (C. aurantiifolia), 0.8 to 4.5 $\mu \mathrm{L} \mathrm{L}^{-1}$ air (C. limon), 2.0 to $12.0 \mu \mathrm{L} \mathrm{L}^{-1}$ air $(M$. indica var. "rosa") and 0.5 to $6.0 \mu \mathrm{L} \mathrm{L}^{-1}$ air ( $M$. indica var. "espada"). The concentrations of compounds for oils ranged from 0.5 to $3.0 \mu \mathrm{L} \mathrm{L}^{-1}$ air (linalool), 0.2 to $3.0 \mu \mathrm{L} \mathrm{L}^{-1}$ air ( $\alpha$-terpineol), 4.0 to $16.0 \mu \mathrm{L} \mathrm{L}^{-1}$ air ( $\alpha$-pinene), 4.0 to $14.0 \mu \mathrm{L} \mathrm{L}^{-1}$ air $(\beta$ pinene), 2.0 to $6.0 \mu \mathrm{L} \mathrm{L}^{-1}$ air (terpinolene), 2.0 to 8.0 $\mu \mathrm{L} \mathrm{L}^{-1}$ air (limonene) and 0.04 to $1.0 \mu \mathrm{L} \mathrm{L}^{-1}$ air (eugenol). Nothing was applied in the control treatment. Immediately after the application of the oil/compound, the fumigation chamber was closed and covered with PVC plastic wrap. The number of mortality in treatments and controls was recorded after $24 \mathrm{~h}$. To avoid direct contact of the insects with the filter paper, the fumigation chamber opening was surrounded by a piece of voile.

\section{Fecundity bioassay}

The effects of vapors of essential oils (Citrus spp. and $M$. indica) on the fecundity of $B$. tabaci eggs were determined using the fumigation bioassay method employed by Ribeiro, Camara and Ramos (2016). Hermetically sealed glass containers with capacity of $1.0 \mathrm{~L}$ were used as test chambers. Leaflets from the common bean cultivar "Carioca", collected 25 to 40 days after the seeds had been sown, were used as supports. To keep leaflet turgor, they were placed in vials $(5 \mathrm{~cm}$ height) with cotton plugs moistened with distilled water, then transferred to the fumigation chamber. With the aid of a vacuum adapter, about 15 pairs of whitefly were placed in 
each fumigation chamber. A filter paper strip $(5 \times 2 \mathrm{~cm})$ that worked by releasing the oil that was being evaluated was attached to the center of the inner side of the fumigation chamber lid. Different oil and eugenol concentrations were added with the aid of an automatic pipette. The lowest concentrations were $1.0 \mu \mathrm{L} \mathrm{L}^{-1}$ air (C. reticulata), $3.0 \mu \mathrm{L} \mathrm{L}^{-1}$ air $(C$. sinensis $\mathrm{x} C$. reticulata), $0.125 \mu \mathrm{L} \mathrm{L}^{-1}$ air (C. aurantiifolia), $0.8 \mu \mathrm{L} \mathrm{L}^{-1}$ air (C. limon), $2.0 \mu \mathrm{L} \mathrm{L}^{-1}$ air (M. indica var. "rosa") and $0.5 \mu \mathrm{L} \mathrm{L} \mathrm{L}^{-1}$ air (M. indica var. "espada"). The concentrations of compounds for the oils were equal to $0.5 \mu \mathrm{L} \mathrm{L}^{-1}$ air (linalool), $0.2 \mu \mathrm{L} \mathrm{L}^{-1}$ air ( $\alpha$-terpineol), $4.0 \mu \mathrm{L} \mathrm{L}^{-1}$ air ( $\alpha$-pinene), $4.0 \mu \mathrm{L} \mathrm{L}^{-1}$ air ( $\beta$-pinene), $2.0 \mu \mathrm{L} \mathrm{L}^{-1}$ air (terpinolene), $2.0 \mu \mathrm{L} \mathrm{L}^{-1}$ air (limonene) and $0.04 \mu \mathrm{L} \mathrm{L}^{-1}$ air (eugenol). Nothing was applied in the control treatment. Immediately after the application of the oil/compound, the fumigation chamber was closed and covered with PVC $\left({ }^{\circ}\right.$ plastic wrap. A completely randomized design was employed, with five replicates, totaling 10 repetitions. The number of eggs in the treatments and controls were recorded after $24 \mathrm{~h}$. To avoid direct contact of the insects with the filter paper, the fumigation chamber opening was surrounded by a piece of voile.

\section{Statistical analysis}

To estimate the curve slopes, $\mathrm{LC}_{50}$ (lethal concentration) of each essential oil (Citrus spp. and $M$. indica) and selected constituents, mortality data were submitted to PROBIT analysis (FINNEY, 1971) using SAS software (version 9.0) (SAS INSTITUTE, 2002). The concentrations used were calculated based on the logarithmic series proposed by Robertson et al. (2017). The fecundity bioassay data were submitted to analysis of variance using PROC ANOVA with the means compared by the Tukey test $(\mathrm{P}<0.05)$ estimated using Statistical Analysis System software (SAS INSTITUTE, 2002).

\section{RESULTS AND DISCUSSION}

\section{Yields and chemical profile of essential oils}

The yields of the essential oils from the peels of Citrus species and latex of $M$. indica varieties obtained through hydrodistillation are presented in Table 1. The highest yields were found for the oils from the latex of the mangoes. The yield of the "rosa" variety $(9.12 \pm 0.16 \%)$ was 1.63 -fold greater than that of the "espada" variety $(5.60 \pm 0.13 \%)$. These yields are in agreement with previous reports found in the literature (RAMOS et al., 2014). Regarding the yields of the essential oils from the peels of fruits of the Citrus species, the highest values were found for tangerine (C. reticulata $\mathrm{x}$ C. sinensis $)(2.05 \pm 0.03 \%)$ and mandarin orange (C. reticulata) $(1.31 \pm 0.21 \%)$, followed by lemon $(C$. limon $)(0.81 \pm 0.06 \%)$ and lime $(C$. aurantiifolia $)$ $(0.48 \pm 0.03 \%)$. These yields are in agreement with the values reported in the literature, which vary from 0.005 to $2.04 \%$ for tangerine and orange (OTHMAN et al., 2016) and from 0.23 to $2.2 \%$ for lemon and lime (GHOORCHIBEIGI et al., 2017; TCHAMENI et al., 2018.

The GC/MS analysis of the oils of the four species of Citrus enabled the identification of 56 compounds accounting for $96.80 \pm 1.13,96.53 \pm$ $1.80,95.43 \pm 0.98$ and $92.05 \pm 1.10 \%$ of the chemical composition of oils from the peels of $C$. reticulata $\mathrm{x} C$. sinensis, $C$. reticulata, $C$. aurantiifolia and $C$. limon, respectively. The oils were characterized by an abundance of monoterpenes, with limonene as the major component. This result is in agreement with reports on the oil from the peel of $C$. aurantiifolia from Vietnam (DANG et al., 2016) and Cameroon (TCHAMENI et al., 2018), C. limon in Iran (GHOORCHIBEIGI et al., 2017) as well as $C$. reticulata in Vietnam (DANG et al., 2016) and Egypt (HAMDAN; MOHAMED; EL-SHAZLY, 2016).

Twenty-one compounds were found in $M$. indica, accounting for $94.52 \pm 0.61$ and $93.96 \pm$ $0.75 \%$ of the chemical composition of the oils from the latex of the "espada" and "rosa" varieties, respectively. Terpinolene was the major constituent in both oils. This is in agreement with findings described by Loveys et al. (1992), who investigated oils from the latex of two other varieties of mango (Kensington and Irwin). Moreover, the occurrence of terpinolene has been reported in the chemical composition of oils from different organs of the plant, particularly the fruit (PINO et al., 2005). 
N. C. RIBEIRO et al.

Table 1. Yields and chemical profiles of essential oils from peels of Citrus species and latex of Mangifera indica varieties.

\begin{tabular}{|c|c|c|c|c|c|c|c|c|}
\hline \multirow{2}{*}{ Compounds } & \multirow{2}{*}{ RIL } & \multirow{2}{*}{ RIC } & $\mathrm{TM}$ & $\mathrm{TC}$ & $\mathrm{LT}$ & LS & $\mathrm{ME}$ & MR \\
\hline & & & $\% \pm \mathrm{SE}$ & $\% \pm \mathrm{SE}$ & $\% \pm \mathrm{SE}$ & $\% \pm \mathrm{SE}$ & $\% \pm \mathrm{SE}$ & $\% \pm \mathrm{SE}$ \\
\hline Yield $(\%) \pm \mathrm{SE}$ & & & $2.05 \pm 0.07$ & $1.31 \pm 0.21$ & $0.81 \pm 0.06$ & $0.48 \pm 0.03$ & $5.60 \pm 0.13$ & $9.12 \pm 0.16$ \\
\hline$\alpha$-Thujene ${ }^{\mathrm{RI}, \mathrm{MS}}$ & 924 & 925 & $0.59 \pm 0.02$ & $0.10 \pm 0.00$ & $0.68 \pm 0.01$ & - & - & - \\
\hline$\alpha$-Pinene ${ }^{R I, ~ M S, ~ C O ~}$ & 932 & 933 & $3.14 \pm 0.08$ & $2.04 \pm 0.10$ & $3.78 \pm 0.11$ & $0.77 \pm 0.02$ & $1.03 \pm 0.09$ & $11.50 \pm 0.21$ \\
\hline$\alpha$-Fenchene $\mathrm{R}^{\mathrm{RI}, \mathrm{MS}}$ & 945 & 941 & - & - & - & $3.84 \pm 0.12$ & - & - \\
\hline Camphene $^{\mathrm{RI}, \mathrm{MS}}$ & 946 & 954 & - & - & - & $0.29 \pm 0.01$ & - & $0.30 \pm 0.02$ \\
\hline Sabinene $\mathrm{R}^{\mathrm{RI}, \mathrm{MS}}$ & 969 & 970 & $1.08 \pm 0.02$ & $2.52 \pm 0.08$ & - & - & - & $1.90 \pm 0.09$ \\
\hline$\beta$-Pinene ${ }^{\mathrm{RI}, \mathrm{MS}, \mathrm{CO}}$ & 974 & 982 & $1.67 \pm 0.09$ & - & $9.89 \pm 0.34$ & $18.14 \pm 0.68$ & $2.21 \pm 0.03$ & $28.42 \pm 0.80$ \\
\hline Myrcene ${ }^{R I, ~ M S, ~ C O ~}$ & 988 & 992 & $4.61 \pm 0.08$ & $6.50 \pm 0.13$ & $0.58 \pm 0.05$ & $2.50 \pm 0.02$ & - & - \\
\hline$\delta$-2-Carene $\mathrm{e}^{\mathrm{RI}, \mathrm{MS}}$ & 1001 & 997 & - & - & - & - & $0.61 \pm 0.00$ & - \\
\hline$p$-Mentha-1 (7),8-diene ${ }^{\mathrm{RI}, \mathrm{MS}}$ & 1003 & 1002 & $4.12 \pm 0.11$ & $0.68 \pm 0.01$ & - & - & - & - \\
\hline$\delta$-3-carene $\mathrm{e}^{\mathrm{RI}, \mathrm{MS}}$ & 1008 & 1005 & - & - & - & - & $6.43 \pm 0.11$ & $2.09 \pm 0.01$ \\
\hline$\alpha$-Terpinene $\mathrm{RI}^{\mathrm{RI}, \mathrm{MS}, \mathrm{CO}}$ & 1014 & 1012 & - & - & - & - & $3.52 \pm 0.09$ & $1.00 \pm 0.08$ \\
\hline Limonene $^{\mathrm{RI}, \mathrm{MS}, \mathrm{CO}}$ & 1024 & 1021 & $60.96 \pm 1.01$ & $77.79 \pm 1.73$ & $37.73 \pm 0.86$ & $40.70 \pm 1.13$ & $1.42 \pm 0.10$ & $1.31 \pm 0.03$ \\
\hline Sylvestrene $\mathrm{RI}^{\mathrm{RI}, \mathrm{MS}}$ & 1025 & 1025 & - & - & - & - & $0.90 \pm 0.00$ & $0.70 \pm 0.00$ \\
\hline$(E)-\beta$-ocimene $\mathrm{RI}^{\mathrm{RI}, \mathrm{MS}}$ & 1044 & 1039 & - & - & - & - & - & $0.60 \pm 0.07$ \\
\hline$\gamma$-Terpinene $\mathrm{e}^{\mathrm{RI}, \mathrm{MS}, \mathrm{CO}}$ & 1050 & 1050 & - & - & - & - & $0.43 \pm 0.01$ & $0.20 \pm 0.01$ \\
\hline$p$-Mentha - 3,8-diene $\mathrm{RI}^{\mathrm{RI}, \mathrm{MS}}$ & 1068 & 1066 & - & $0.01 \pm 0.00$ & - & $0.29 \pm 0.01$ & - & - \\
\hline$p$-Mentha $-2,4(8)$-diene $\mathrm{e}^{\mathrm{RI}, \mathrm{MS}}$ & 1085 & 1070 & $9.80 \pm 0.21$ & $1.46 \pm 0.05$ & $5.53 \pm 0.09$ & $1.15 \pm 0.02$ & - & - \\
\hline Terpinolene $^{\mathrm{RI}, \mathrm{MS}, \mathrm{CO}}$ & 1086 & 1093 & $1.37 \pm 0.03$ & $0.10 \pm 0.00$ & $1.26 \pm 0.03$ & - & $70.14 \pm 0.61$ & $39.24 \pm 0.29$ \\
\hline Linalool $^{\mathrm{RI}, \mathrm{MS}, \mathrm{CO}}$ & 1095 & 1103 & $4.41 \pm 0.12$ & $3.56 \pm 0.07$ & $3.00 \pm 0.07$ & $0.10 \pm 0.00$ & - & - \\
\hline exo-Fenchol ${ }^{\mathrm{RI}, \mathrm{MS}}$ & 1118 & 1118 & - & - & $0.19 \pm 0.00$ & $1.06 \pm 0.02$ & - & - \\
\hline$c i s$-Limonene oxide ${ }^{\mathrm{RI}, \mathrm{MS}}$ & 1132 & 1136 & - & - & $0.49 \pm 0.02$ & $0.29 \pm 0.00$ & - & - \\
\hline trans-Limonene oxide ${ }^{\mathrm{RI}, \mathrm{MS}}$ & 1137 & 1140 & - & - & $0.68 \pm 0.08$ & - & - & - \\
\hline (E)-Myroxide ${ }^{\mathrm{RI}, \mathrm{MS}}$ & 1140 & 1146 & - & - & $0.49 \pm 0.01$ & $0.58 \pm 0.00$ & - & - \\
\hline$\beta$-Pinene oxide ${ }^{\mathrm{RI}, \mathrm{MS}}$ & 1154 & 1151 & - & - & - & $1.34 \pm 0.11$ & - & - \\
\hline iso-Menthone $^{\mathrm{RI}, \mathrm{MS}}$ & 1158 & 1154 & $0.29 \pm 0.00$ & $0.10 \pm 0.00$ & - & - & - & - \\
\hline Terpinen-4-ol ${ }^{\mathrm{RI}, \mathrm{MS}}$ & 1174 & 1177 & $0.78 \pm 0.01$ & $0.27 \pm 0.01$ & $2.62 \pm 0.09$ & $2.21 \pm 0.08$ & - & - \\
\hline$p$-Cymen-8-ol ${ }^{\mathrm{RI}, \mathrm{MS}}$ & 1179 & 1180 & - & - & - & - & - & - \\
\hline$\alpha$-Terpineol ${ }^{\mathrm{RI}, \mathrm{MS}}$ & 1186 & 1191 & $1.08 \pm 0.08$ & $0.28 \pm 0.00$ & $5.04 \pm 0.14$ & $2.78 \pm 0.08$ & - & - \\
\hline$n$-Decanal ${ }^{\mathrm{RI}, \mathrm{MS}}$ & 1201 & 1206 & $1.76 \pm 0.10$ & $0.49 \pm 0.00$ & $0.29 \pm 0.00$ & - & - & - \\
\hline cis-Carveol $^{\mathrm{RI}, \mathrm{MS}}$ & 1226 & 1225 & - & - & $0.19 \pm 0.00$ & - & - & - \\
\hline Nerol $^{\text {RI, MS }}$ & 1227 & 1234 & $0.20 \pm 0.00$ & - & $0.68 \pm 0.02$ & $0.38 \pm 0.01$ & - & - \\
\hline Neral $^{\text {RI, MS }}$ & 1235 & 1246 & - & - & $2.43 \pm 0.08$ & $0.28 \pm 0.00$ & - & - \\
\hline Geranial $^{\mathrm{RI}, \mathrm{MS}}$ & 1264 & 1261 & - & - & $0.78 \pm 0.00$ & $2.55 \pm 0.00$ & - & - \\
\hline Isopulegyl acetate ${ }^{\mathrm{RI}, \mathrm{MS}}$ & 1274 & 1271 & & & & & $0.54 \pm 0.01$ & $0.10 \pm 0.01$ \\
\hline Neryl formate ${ }^{\mathrm{RI}, \mathrm{MS}}$ & 1280 & 1276 & - & - & $2.72 \pm 0.08$ & $2.59 \pm 0.09$ & - & - \\
\hline$\delta$-Elemene $\mathrm{RI}^{\mathrm{RI}}$ & 1335 & 1336 & $0.10 \pm 0.00$ & - & $0.19 \pm 0.00$ & - & - & - \\
\hline Citronellyl acetate $^{\mathrm{RI}, \mathrm{MS}}$ & 1350 & 1351 & $0.09 \pm 0.00$ & $0.02 \pm 0.00$ & - & - & - & - \\
\hline Nerila acetate $^{\mathrm{RI}, \mathrm{MS}}$ & 1359 & 1361 & - & - & $3.30 \pm 0.14$ & $0.38 \pm 0.01$ & - & - \\
\hline Geranyl acetate ${ }^{\mathrm{RI}, \mathrm{MS}}$ & 1379 & 1380 & - & - & $1.16 \pm 0.09$ & $0.38 \pm 0.00$ & - & - \\
\hline Daucene $^{\mathrm{RI}, \mathrm{MS}}$ & 1380 & 1425 & - & $0.10 \pm 0.00$ & - & - & - & - \\
\hline
\end{tabular}

SE: Standard Error; RIL: Retention indices from the literature; RIC: Retention indices calculated from retention times in relation to those of a series of $\mathrm{C}_{8}-\mathrm{C}_{40} \mathrm{n}$-alkanes on a DB-5 capillary column; Method of identification: RI: Retention Index; MS: Mass Spectroscopy; CO: Co-Injection with authentic compounds; LT: Citrus aurantiifolia; LS: C. limon; TM: C. sinensis x C. reticulata ; TC: C. reticulata ; MR: Mangifera indica var. "rosa" (MR) and ME: $M$. indica var. "espada" (ME). 
Table 1. Continuation.

\begin{tabular}{|c|c|c|c|c|c|c|c|c|}
\hline \multirow{2}{*}{ Compounds } & \multirow{2}{*}{ RIL } & \multirow{2}{*}{ RIC } & TM & $\mathrm{TC}$ & LT & LS & ME & MR \\
\hline & & & $\% \pm \mathrm{SE}$ & $\% \pm \mathrm{SE}$ & $\% \pm \mathrm{SE}$ & $\% \pm \mathrm{SE}$ & $\% \pm \mathrm{SE}$ & $\% \pm \mathrm{SE}$ \\
\hline Yield $(\%) \pm \mathrm{SE}$ & & & $2.05 \pm 0.07$ & $1.31 \pm 0.21$ & $0.81 \pm 0.06$ & $0.48 \pm 0.03$ & $5.60 \pm 0.13$ & $9.12 \pm 0.16$ \\
\hline$\beta$-Cubebene $\mathrm{RI}^{\mathrm{RI}, \mathrm{MS}}$ & 1387 & 1388 & - & $0.08 \pm 0.01$ & $0.01 \pm 0.00$ & - & - & - \\
\hline$\beta$-Elemene ${ }^{\mathrm{RI}, \mathrm{MS}}$ & 1389 & 1389 & $0.05 \pm 0.00$ & - & $0.01 \pm 0.00$ & - & - & - \\
\hline Ethyl geranate $^{\mathrm{RI}, \mathrm{MS}}$ & 1394 & 1396 & - & - & - & $0.77 \pm 0.01$ & - & - \\
\hline$\beta$-Longipinene $\mathrm{R}^{\mathrm{RI}, \mathrm{MS}}$ & 1400 & 1400 & - & - & - & - & $0.82 \pm 0.02$ & $2.90 \pm 0.10$ \\
\hline Cycloseychellene $\mathrm{e}^{\mathrm{RI}, \mathrm{MS}}$ & 1406 & 1407 & - & - & - & - & $0.41 \pm 0.01$ & $0.20 \pm 0.00$ \\
\hline$\alpha$-cis-Bergamotene & 1411 & 1414 & - & - & $0.28 \pm 0.00$ & - & - & - \\
\hline$\beta$-Caryophyllene ${ }^{\mathrm{RI}, \mathrm{MS}, \mathrm{CO}}$ & 1417 & 1421 & - & - & $1.16 \pm 0.10$ & $0.31 \pm 0.00$ & - & - \\
\hline$\alpha$-trans-Bergamotene $\mathrm{e}^{\mathrm{RI}, \mathrm{MS}}$ & 1432 & 1434 & - & - & $2.91 \pm 0.10$ & $0.30 \pm 0.00$ & - & - \\
\hline$\gamma$-Elemene ${ }^{\text {RI, MS }}$ & 1434 & 1438 & & & & & $0.28 \pm 0.00$ & $1.50 \pm 0.08$ \\
\hline$\alpha$-Guaiene ${ }^{\mathrm{RI}, \mathrm{MS}}$ & 1437 & 1436 & - & - & - & $1.15 \pm 0.00$ & - & - \\
\hline Citronellyl propanoate ${ }^{\mathrm{RI}, \mathrm{MS}}$ & 1444 & 1442 & - & - & - & - & - & $0.13 \pm 0.03$ \\
\hline$\alpha$-Clovene $\mathrm{R}^{\mathrm{RI}, \mathrm{MS}}$ & 1452 & 1449 & - & - & - & - & $0.61 \pm 0.08$ & $0.30 \pm 0.01$ \\
\hline$(E)-\beta$-Farnesene $\mathrm{e}^{\mathrm{RI}, \mathrm{MS}}$ & 1454 & 1453 & $0.10 \pm 0.00$ & - & $0.48 \pm 0.03$ & $2.88 \pm 0.15$ & - & - \\
\hline$\beta$-Santalene $\mathrm{e}^{\mathrm{RI}, \mathrm{MS}}$ & 1457 & 1457 & - & - & $0.20 \pm 0.00$ & - & - & - \\
\hline Cumacrene $\mathrm{RI}^{\mathrm{RI} M S}$ & 1470 & 1471 & - & $0.03 \pm 0.00$ & $0.01 \pm 0.00$ & - & - & - \\
\hline$\gamma$-Gurjunene RI, MS $^{\text {Re }}$ & 1475 & 1472 & - & - & - & - & $3.68 \pm 0.13$ & $1.34 \pm 0.02$ \\
\hline Geranyl propanoate ${ }^{\mathrm{RI}, \mathrm{MS}}$ & 1476 & 1474 & - & - & $0.41 \pm 0.01$ & $0.38 \pm 0.00$ & & \\
\hline$\gamma$-Muurolene $\mathrm{e}^{\mathrm{RI}, \mathrm{MS}}$ & 1478 & 1477 & $0.20 \pm 0.00$ & $0.10 \pm 0.00$ & - & - & & \\
\hline$\gamma$-Muurolene $\mathrm{RI}^{\mathrm{RI}, \mathrm{MS}}$ & 1478 & 1477 & & & & & $0.42 \pm 0.00$ & - \\
\hline$\gamma$-Himachalene $\mathrm{RI}^{\mathrm{RI}, \mathrm{MS}}$ & 1481 & 1478 & & & & & $0.60 \pm 0.04$ & $0.21 \pm 0.01$ \\
\hline Valencene $\mathrm{R}^{\mathrm{RI}, \mathrm{MS}}$ & 1496 & 1497 & - & - & $0.38 \pm 0.00$ & $0.29 \pm 0.00$ & - & - \\
\hline$(E, E)-\alpha$-Farnesene ${ }^{\mathrm{RI}, \mathrm{MS}}$ & 1505 & 1502 & $0.10 \pm 0.00$ & $0.20 \pm 0.00$ & - & - & - & - \\
\hline$\beta$-Bisabolene $\mathrm{e}^{\mathrm{RI}, \mathrm{MS}}$ & 1505 & 1510 & - & - & $4.17 \pm 0.17$ & - & - & - \\
\hline$\beta$-Sesquiphellandrene $\mathrm{e}^{\mathrm{RI}, \mathrm{MS}}$ & 1521 & 1525 & - & - & - & $4.03 \pm 0.17$ & - & - \\
\hline$\delta$-Cadinene ${ }^{\mathrm{RI}, \mathrm{MS}}$ & 1522 & 1529 & $0.10 \pm 0.00$ & $0.10 \pm 0.00$ & - & - & - & - \\
\hline Germacrene $\mathrm{B}^{\mathrm{RI}, \mathrm{MS}}$ & 1559 & 1554 & $0.20 \pm 0.00$ & - & - & - & - & - \\
\hline Caryophyllene oxide ${ }^{\mathrm{RI}, \mathrm{MS}, \mathrm{CO}}$ & 1582 & 1583 & - & - & $0.68 \pm 0.08$ & - & - & - \\
\hline Humulene epoxide II $^{\mathrm{RI}, \mathrm{MS}}$ & 1608 & 1606 & - & - & $0.20 \pm 0.00$ & $1.34 \pm 0.10$ & - & - \\
\hline Selin-11-en-4- $\alpha-$ ol $^{\mathrm{RI}, \mathrm{MS}}$ & 1658 & 1653 & - & - & $0.18 \pm 0.01$ & - & - & - \\
\hline epi- $\beta$-Bisabolol ${ }^{\mathrm{RI}, \mathrm{MS}}$ & 1670 & 1666 & - & - & $0.27 \pm 0.00$ & - & - & - \\
\hline$e i_{-} \alpha-$ Bisabolol $^{\mathrm{RI}, \mathrm{MS}}$ & 1683 & 1682 & - & - & $0.38 \pm 0.00$ & - & - & - \\
\hline Total & & & $96.80 \pm 1.13$ & $96.53 \pm 1.80$ & $95.43 \pm 0.98$ & $92.05 \pm 1.10$ & $94.52 \pm 0.61$ & $93.96 \pm 0.75$ \\
\hline Monoterpenes & & & $93.77 \pm 1.00$ & $95.46 \pm 1.77$ & $83.78 \pm 0.80$ & $81.68 \pm 1.14$ & $87.41 \pm 0.46$ & $87.35 \pm 0.41$ \\
\hline Sesquiterpenes & & & $0.78 \pm 0.05$ & $0.58 \pm 0.01$ & $11.35 \pm 0.20$ & $10.37 \pm 0.15$ & $7.11 \pm 0.18$ & $6.61 \pm 0.10$ \\
\hline Fatty acid derivatives & & & $2.25 \pm 0.00$ & $0.49 \pm 0.00$ & $0.29 \pm 0.00$ & - & - & - \\
\hline
\end{tabular}

SE: Standard Error; RIL: Retention indices from the literature; RIC: Retention indices calculated from retention times in relation to those of a series of $\mathrm{C}_{8}-\mathrm{C}_{40}$ n-alkanes on a DB-5 capillary column; Method of identification: RI: Retention Index; MS: Mass Spectroscopy; CO: Co-Injection with authentic compounds; LT: Citrus aurantiifolia; LS: C. limon; TM: $C$. sinensis x C. reticulata ; TC: C. reticulata ; MR: Mangifera indica var. "rosa" (MR) and ME: $M$. indica var. "espada" (ME). 


\section{Fumigant bioassay}

The insecticidal action found when $B$. tabaci was exposed to the vapors of the oils from the Citrus species and two varieties of $M$. indica varied according to the type of oil (Table 2).

The whitefly was more susceptible to the oils of lime and lemon (C. aurantiifolia and C. limon), followed by those of $C$. reticulata, $C$. sinensis $\mathrm{x} C$. reticulata, $M$. indica var. "espada" and "rosa". With the exception of the oil from $C$. aurantiifolia, which had the same level of toxicity as eugenol, used as the positive control, none of the oils investigated was more active against $B$. tabaci than this phenylpropanoid (Table 2).

Table 2. Fumigant action of essential oils from Citrus species and Mangifera indica varieties, selected compounds and positive control (eugenol) on Bemisia tabaci biotype B

\begin{tabular}{|c|c|c|c|c|c|c|}
\hline Essential oils & $\mathbf{N}$ & DF & Slope \pm SE & $\begin{array}{c}\mathrm{LC}_{50} \mu \mathrm{L} \mathrm{\textrm {L } ^ { - 1 }} \text { air } \\
(\mathrm{CI} 95 \%)\end{array}$ & $\chi^{2}$ & p-value \\
\hline C. reticulata & 388 & 3 & $4.26 \pm 0.85$ & $3.04(2.22-3.59)$ & 2.19 & 0.41 \\
\hline$C$. sinensis $\mathrm{x} C$. reticulata & 452 & 3 & $7.62 \pm 1.16$ & $5.39(3.99-6.10)$ & 3.80 & 0.33 \\
\hline C. aurantiifolia & 305 & 3 & $1.75 \pm 0.28$ & $0.70(0.13-1.43)$ & 3.40 & 0.29 \\
\hline C. limon & 322 & 3 & $3.87 \pm 0.69$ & $1.77(0.63-2.44)$ & 4.18 & 0.18 \\
\hline M. indica var. "rosa" & 630 & 4 & $8.08 \pm 1.14$ & $7.95(6.08-8.91)$ & 9.30 & 0,06 \\
\hline M. indica var. "espada" & 540 & 3 & $6.36 \pm 0.81$ & $3.27(2.25-3.93)$ & 7.40 & 0.09 \\
\hline \multicolumn{7}{|l|}{ Compounds } \\
\hline Eugenol & 495 & 4 & $1.96 \pm 0.32$ & $0.20(0.02-0.34)$ & 9.37 & 0.06 \\
\hline Linalool & 540 & 3 & $5.06 \pm 0.69$ & $1.60(0.97-1.99)$ & 7.42 & 0.09 \\
\hline$\alpha$-terpineol & 540 & 3 & $4.93 \pm 0.57$ & $1.43(1.05-1.73)$ & 6.35 & 0.11 \\
\hline$\alpha$-pinene & 630 & 4 & $9.20 \pm 1.13$ & $11.37(10.16-12.22)$ & 5.15 & 0.17 \\
\hline$\beta$-pinene & 630 & 4 & $5.19 \pm 0.50$ & $7.40(6.17-8.37)$ & 6.71 & 0.22 \\
\hline terpinolene & 540 & 3 & $8.36 \pm 1.06$ & $4.21(3.38-4.73)$ & 5.95 & 0.08 \\
\hline Limonene & 540 & 3 & $9.91 \pm 1.02$ & $5.41(4.81 \pm 5.86)$ & 3.90 & 0.34 \\
\hline
\end{tabular}

$\mathrm{N}$ : number of mites; DF: degree of freedom; SE: standard error; LC: lethal concentration values; CI: confidence interval; $\mathrm{c}^{2}$ : chi-square.

Fumigant bioassays were performed to investigate the relative toxicity of some chemical compounds identified in the oils and demonstrated that linalool and $\alpha$-terpineol were the most toxic to $B$. tabaci, followed by terpinolene, limonene, $\beta$-pinene and $\alpha$-pinene. These results indicate that the major component of a mixture is not always the most active. Indeed, the minor constituents found in the Citrus (linalool and $\alpha$-terpineol) were about 3.38fold more toxic than the major constituent (limonene).

The fumigant properties of oils are well known for a wide variety of arthropods (RIBEIRO et al., 2019, MALACRINÒ et al., 2016, PAVELA; BENELLI, 2016), including B. tabaci (YANG et al., 2010). However, this is the first report of the fumigant action of oils from Citrus sinensis x $C$. reticulata, $C$. limon and $M$. indica ("rosa" and "espada" varieties) on the whitefly. A previous investigation of the toxicity of oils from the key lime (Citrus aurantiifolia) and the mandarin orange $(C$. reticulata) grown in South Korea on the Q and $\mathrm{B}$ biotypes of $B$. tabaci revealed toxicity by fumigation only for the Q biotype (KIM et al., 2011), with an estimated $\mathrm{LC}_{50}$ of $0.91 \mathrm{~mL} / \mathrm{cm}^{3}$ for the $C$. aurantiifolia oil.

By comparing these results to those obtained in the present study, it is possible to see that the essential oil from C. aurantiifolia grown in northeast Brazil was more toxic to the whitefly. This difference in toxicity in the experiments conducted in
South Korea and the present investigation may be attributed to the different biotypes tested and the possible qualitative and/or quantitative variations in the chemical composition of the oils.

Investigations evaluating the insecticidal action of the oils from the latex of mangos are rare. However, the insecticidal action of other derivatives, such as aqueous extract of the leaves of $M$. indica, has been evaluated against other agricultural pests and insects of interest to human medicine. For instance, Mohammed and Chadde (2007) and Zuharah et al. (2014) verified the efficacy of the aqueous extract from the leaves of $M$. indica against 3rd instar larvae of Aedes aegypti L. (Diptera: Culicidae). In another study, Devanand and Rani (2008) evaluated the effectiveness of the aqueous extract from the leaves against two important pests of cotton [Spodoptera litura F. (Lepidoptera: Noctuidae)] and castor bean [Achaea janata L. (Noctuidae: Lepidoptera)].

\section{Fecundity Bioassay}

The number of eggs per B. tabaci female when exposed to the Citrus and Mangifera oils is shown in Table 3. The fecundity tests performed with the oils and selected constituents suggest that, at sublethal concentrations, these product reduce the fecundity of the whitefly when compared to the negative control $(\mathrm{F}=560.53 ; \mathrm{DF}=14 ; \mathrm{P}<0.0001)$. 
N. C. RIBEIRO et al.

Table 3. Fecundity (eggs female ${ }^{-1}$ day $^{-1}$ ) of Bemisia tabaci exposed to essential oils of Citrus and Mangifera indica, and applications of selected constituents in laboratory after $24 \mathrm{~h}$.

\begin{tabular}{|c|c|c|c|}
\hline Essential oil or selected constituents & $\mathrm{N}$ & $\begin{array}{l}\text { eggs female }{ }^{-1} \text { day }^{-1} \\
(\text { means } \pm \text { SE) }\end{array}$ & $\mathrm{E}(\%)$ \\
\hline Negative Control & 74 & $9.66 \pm 0.15 \mathrm{~h}^{*}$ & - \\
\hline C. reticulata & 73 & $1.67 \pm 0.12 \mathrm{c}$ & 82.71 \\
\hline C. sinensis $\mathrm{x}$ C. reticulata & 73 & $0.49 \pm 0.05 \mathrm{a}$ & 94.93 \\
\hline C. aurantiifolia & 73 & $1.40 \pm 0.07 \mathrm{c}$ & 85.51 \\
\hline C. limon & 73 & $1.32 \pm 0.09 \mathrm{c}$ & 86.34 \\
\hline M. indica var. "rosa" & 74 & $8.71 \pm 0.15 \mathrm{~g}$ & 9.83 \\
\hline M. indica var. "espada" & 73 & $8.42 \pm 0.14 \mathrm{~g}$ & 12.84 \\
\hline eugenol & 75 & $7.20 \pm 0.20 \mathrm{f}$ & 25.47 \\
\hline Linalool & 73 & $3.41 \pm 0.27 \mathrm{~d}$ & 64.70 \\
\hline$\alpha$-terpineol & 74 & $3.48 \pm 0.13 \mathrm{~d}$ & 63.98 \\
\hline$\alpha$-pinene & 72 & $2.88 \pm 0.14 \mathrm{~d}$ & 70.19 \\
\hline$\beta$-pinene & 73 & $6.31 \pm 0.13 \mathrm{e}$ & 34.68 \\
\hline terpinolene & 74 & $0.51 \pm 0.06 \mathrm{ab}$ & 94.72 \\
\hline Limonene & 74 & $1.17 \pm 0.08 \mathrm{bc}$ & 87.89 \\
\hline
\end{tabular}

The effect on the fecundity of $B$. tabaci varied according to the type of essential oil. The oil from $C$. reticulata $\mathrm{x} C$. sinensis had the greatest effect, reducing the number of eggs laid per female by $94.93 \%$. The other Citrus oils had a somewhat lower effect and did not differ significantly from one another. The oils from the latex of the "rosa" and "espada" varieties of $M$. indica had the least effect on the fecundity of the whitefly, reducing the number of eggs laid per female by 9.83 and $12.84 \%$, respectively.

Regarding the selected constituents, terpinolene was the compound with the most effect on fecundity, reducing the number of eggs laid per $B$. tabaci female by $94.72 \%$, followed by limonene, which achieved an $87.89 \%$ reduction in eggs laid. Linalool, $\alpha$-terpineol and $\alpha$-pinene achieved similar reductions in fecundity (64.80 to $70.19 \%$ ), whereas $\beta$ -pinene had the least effect.

Among the oils tested, those from the species of Citrus were more effective than the positive control (eugenol). Based on the sublethal effects of the monoterpenes investigated, all selected constituents from the Citrus and M. indica oils were more effective at reducing the number of eggs laid per B. tabaci female than eugenol.

This is the first report of the effect of the vapors from essential oils on the fecundity of $B$. tabaci. However, previous reports describe the effect by fumigation on the fecundity of other agricultural pests that occur in protected farming environments. MELO et al. (2018) showed that sublethal concentrations of the oil from Aristolochia trilobata L. (Aristolochiaceae) and the constituents limonene, $\rho$-cymene, linalool and sulcatyl acetate reduced the fecundity of Tetranychus urticae. In another investigation, BORZOUI et al. (2016) report the reduction in the fecundity of Plodia interpunctella (Hübner) (Lepidoptera: Pyralidae) when exposed to sublethal concentrations of the vapors of oils from Artemisia khorassanica Podl. (Asteraceae) and Vitex pseudo-negundo Hausskn. (Lamiaceae).

\section{CONCLUSIONS}

The chemical study of the essential oils from the peels of tangerine, mandarin orange, lemon and lime as well as the latex of two mango varieties demonstrated that the oils were rich in monoterpenes, with limonene as the major constituent of the Citrus oils and terpinolene as the major constituent of the $M$. indica oils. This is the first report of the fumigant properties and effects of these oils on B. tabaci fecundity. The findings reveal that the Citrus and M. indica oils and selected constituents (linalool, $\alpha$-terpineol, $\alpha$-pinene, $\beta$ pinene, terpinolene and limonene) are potentially useful for the future integrated management of $B$. tabaci in protected environments due to their different mechanisms of action, such as toxicity and a reduction in the fecundity of the target pest. However, further studies are needed to investigate the effects of these essential oils on non-target organisms and the cost-benefit ratio for the formulation of an insecticidal agent containing the essential oils from Citrus and Mangifera as the active ingredient.

\section{ACKNOWLEDGEMENT}

This work was supported by Conselho Nacional de Desenvolvimento Científico e Tecnológico (PQ-2-302860/2016-9), Coordenação de Aperfeiçoamento de Pessoal de Nível Superior (CAPES/PROCAD-88887.308194/2018-00) and 
Fundação de Amparo à Ciência e Tecnologia do Estado de Pernambuco-FACEPE (APQ-04761.06/14, APQ-08601.06/16 and APQ- 10081.06/15). The authors would like to thank Dr. Maria R. C. S. de Melo for identifying the botanical species.

\section{REFERENCE}

ADAMS, R. P. Identification of Essential Oil Components by Gas Chromatography-Mass Spectrometry. 4. ed. Carol Stream: Allured Publishing Corporation, 2007. 804 p.

ARAÚJO JÚNIOR, C. P. et al. Acaricidal activity against Tetranychus urticae and chemical composition of peel essential oils of three Citrus species cultivated in NE Brazil. Natural Product Communications, 5: 471-476, 2010.

BARRO, P. J. et al. Bemisia tabaci: A Statement of Species Status. Annual Review of Entomology, 56: $1-19,2011$

BORZOUI, E. et al. Lethal and sublethal effects of essential oils from Artemisia khorassanica and Vitex pseudo-negundo against Plodia interpunctella (Lepidoptera: Pyralidae). Environmental entomology, 45: 1220-1226, 2016.

DAMALAS, C. A.; ELEFTHEROHORINOS, I. G. Pesticide exposure, safety issues, and risk assessment indicators. International Journal of Environmental Research and Public Health, 8: 1402-1419, 2011.

DANG, N. H. et al. Chemical composition and $\alpha$ glucosidase inhibitory activity of vietnamese Citrus peels essential oils. Journal of Chemistry, 2016:1$5,2016$.

DEVANAND, P.; RANI, P. U. Biological potency of certain plant extracts in management of two lepidopteran pests of Ricinus communis L. Journal of Biopesticides, 1: 170-176, 2008.

DOOL, H. V.; KRATZ, P. H. A generalization of the retention index system including linear temperature programmed gas-liquid partition chromatography. Journal of Chromatography A, 11: 463-471, 1963.

FINNEY, D. J. Probit Analysis. 3 ed. Cambridge: University Press, 1971. 304 p.

FOUAD, H. A.; DA CAMARA, C. A. Chemical composition and bioactivity of peel oils from Citrus aurantiifolia and Citrus reticulata and enantiomers of their major constituent against Sitophilus zeamais (Coleoptera: Curculionidae). Journal of Stored Products Research, 73: 30-36, 2017.
GHOORCHIBEIGI, M. et al. Chemical composition and radical scavenging activity of Citrus limon peel essential oil. Oriental Journal Of Chemistry, 33: 458-461, 2017.

HAMDAN, D. I.; MOHAMED, M. E.; ELSHAZLY, A. M. Citrus reticulata Blanco cv. Santra leaf and fruit peel: A common waste products, volatile oils composition and biological activities. Journal of Medicinal Plants Research, 10: 457 $467,2016$.

ISMAN, M. B.; GRIENEISEN, M. L. Botanical insecticide research: many publications, limited useful data. Trends in Plant Science, 19: 140-145, 2014.

KIM, S. et al. Contact and fumigant toxicity of plant essential oils and efficacy of spray formulations containing the oils against B- and Q-biotypes of Bemisia tabaci. Pest Management Science, 67: 1093-1099, 2011.

LOVEYS, B. R. et al. Mango sapburn: components of fruit sap and their role in causing skin damage. Functional Plant Biology, 9: 449-457, 1992.

MALACRINÒ, A. et al. Fumigant and repellent activity of limonene enantiomers against Tribolium confusum du Val. Neotropical entomology, 45: 597 603, 2016.

MALUMPHY, C. Diagnostic protocols for regulated pests-Bemisia tabaci. EPPO bulletin, 34: 281-288, 2004.

MELO, J. P. R. et al. Acaricidal properties of the essential oil from Aristolochia trilobata and its major constituents against the two-spotted spider mite (Tetranychus urticae). Canadian Journal of Plant Science, 98: 1342-1348, 2018.

MOHAMMED, A.; CHADEE, D. D. An evaluation of some Trinidadian plant extracts against larvae of Aedes aegypti mosquitoes. Journal of the American Mosquito Control Association, 23: 172-176, 2007.

OTHMAN, S. N. A. M. et al. Essential oils from the Malaysian Citrus (Rutaceae) medicinal plants. Medicines, 3: 1-13, 2016.

PAVELA, R.; BENELLI, G. Essential oils as ecofriendly biopesticides? Challenges and constraints. Trends in plant science, 21: 1000-1007, 2016.

PINO, J. A. et al. Volatile components from mango (Mangifera indica L.) cultivars. Journal of Agricultural and Food Chemistry, 53: 2213-2223, 2005. 
RAMOS, E. H. S. et al. Chemical composition, leishmanicidal and cytotoxic activities of the essential oils from Mangifera indica L. var. Rosa and Espada. BioMed Research International, 2014: 19, 2014.

RATHORE, H. S.; NOLLET, L. M. Green Pesticides Handbook: essential oils for pest control. 1. ed. Boca Raton: CRC Press, 2017. 570 p.

REIS, N. V. B. Construção de Estufas para Produção de Hortaliças nas Regiões Norte, Nordeste e Centro-Oeste. 1. ed. Brasília, DF: Embrapa Hortaliças, 2005. 16 p.

RIBEIRO, N. C. et al. Acaricidal properties of essential oils from agro-industrial waste products from citric fruit against Tetranychus urticae. Journal of Applied Entomology, 143: 731-743, 2019.

RIBEIRO, N. C. et al. Insecticidal activity against Bemisia tabaci biotype B of peel essential oil of Citrus sinensis var. pear and Citrus aurantium cultivated in northeast Brazil. Natural Product Communications, 5: 1819-1822, 2010.

RIBEIRO, N.; CAMARA, C.; RAMOS, C. Toxicity of essential oils of Piper marginatum Jacq. against Tetranychus urticae Koch and Neoseiulus californicus (McGregor). Chilean Journal of Agricultural Research, 76: 71-76, 2016.

ROBERTSON, J. L. et al. Bioassays with Arthropods. 3. ed. Boca Raton: CRC press, 2017. $212 \mathrm{p}$.

SAS Institute. The SAS System for Windows Version 9.0. Cary: SAS Institute, 2002.

TCHAMENI, S. N. et al. Using Citrus aurantifolia essential oil for the potential biocontrol of Colocasia esculenta (taro) leaf blight caused by Phytophthora colocasiae. Environmental Science and Pollution Research, 25: 29929-29935, 2018.

YANG, N. et al. Effects of plant essential oils on immature and adults sweetpotato whitefly, Bemisia tabaci biotype B. Crop Protection, 29: 1200-1207, 2010.

ZUHARAH, W. F. et al. Larvicidal efficacy screening of Anacardaciae crude extracts on the dengue hemorrhagic vector, Aedes aegypti. Tropical Biomedicine, 31: 297-304, 2014. 